\title{
INFLUENCE OF IMPURITIES IN RAW MATERIAL ON SENSORY AND PHYSICOCHEMICAL PROPERTIES OF COLD-PRESSED RAPESEED OIL PRODUCED FROM CONVENTIONALLY AND ECOLOGICALLY GROWN SEEDS
}

\author{
Małgorzata Wroniak ${ }^{\bowtie}$, Agnieszka Rękas, Katarzyna Ratusz \\ Department of Food Technology, Warsaw University of Life Sciences - SGGW \\ Nowoursynowska 159C, 02-776 Warsaw, Poland
}

\begin{abstract}
Background. The main problem of cold-pressed technology is its low yield and the varying quality of the end product, which is dependent on the quality of the raw material, technological process applied and also on conditions of packaging and storage. The effects of different contents of impurities in rapeseed on the sensory, physicochemical properties and oxidative stability of rapeseed oil produced by cold-pressing were investigated.

Material and methods. Cold-pressed oil produced from conventionally grown rapeseeds (individual cultivars and industrial seeds) and certified ecological rapeseeds. Quantified quality parameters included the following: the content of impurities, acid value, peroxide value, spectrophotometric indices $\left(K_{232}, K_{268}\right)$, oxidative stability determined by the Rancimat test, pheophytin $a$ content, and sensory assessment.

Results. The seeds which were homogenous in terms of cultivar contained the lowest level of impurities (up to $1.3 \%$ ) and differed significantly in this regard from ecological and industrial seeds. It was found that the presence of impurities exerts an adverse effect on the sensory and physicochemical characteristics of the oil. Impurity content exceeding 5\% resulted in the appearance of off-flavours, such as woody, strawy and fusty/ musty. Furthermore, a positive correlation was found between impurity content and acid value $(r=0.781)$, peroxide value $(r=0.656)$, anisidine value $(r=0.645), K_{232}(r=0.625)$, while in the case of oxidative stability, no such correlation was observed.

Conclusions. The type and percentage of seed impurities in the rape crop determines the sensory and physicochemical properties of the cold-pressed oil. It seems advisable, therefore, to minimize the amount of impurities, in order to obtain high-quality cold-pressed rapeseed oil.
\end{abstract}

Key words: rapeseed, impurities, cold-pressing, quality indices, sensory evaluation, oxidative stability

\section{INTRODUCTION}

Cold-pressed oils are gaining popularity among producers and consumers not only in Poland but also abroad (Koski et al., 2002; Matthäus and Brühl, 2003; Matthäus and Brühl, 2008; Matthäus and Spener, 2008). Their production technology is cheap, simple and, above all, environment-friendly (Matthäus, 2012). Unlike the industrial production of popular refined edible oils, it does not require the use of toxic and ozone layer-destroying hexane nor chemical agents to refine the extracted oil (no toxic wastewater) (Koski et al., 
2002). Nevertheless, the main problem of cold-pressing technology is its low yield and the varying quality of the end product, which is dependent on the quality of the raw material, the technological process applied and also the conditions of packaging and storage (Matthäus, 2012; Matthäus and Spener, 2008; Rotkiewicz and Konopka, 1998; Rotkiewicz et al., 2002). There are no uniform legal regulations related to the quality of raw materials used for cold-pressed oil production, but there are different national and international standards such as Codex Alimentatrius, which specify requirements pertaining to the quality of cold-pressed oils. It is more difficult to ensure the high quality and safety of cold-pressed oils since it is not possible to carry out any purification after the pressing process (Matthäus, 2012; Pekkarinen et al., 1998; Wroniak et al., 2008).

The popularity of olive oil produced exclusively with physical methods and considered as an extremely noble and healthy food product in Europe and beyond undoubtedly contributes to the growing interest in other types of cold-pressed oils. The most common edible oil in Poland is rapeseed oil, which is characterized by a valuable fatty acid composition. The predominating fatty acid in both these oils is monoenoic oleic fatty acid. For this reason, calling rapeseed oil (especially that produced by cold-pressing) "the olive oil of the north" is completely substantiated. In addition, rapeseed oil contains a scarce polyenoic fatty acid $-\alpha$-linolenic acid, whereas the ratio of its $n-6 / n-3$ fatty acids is considered optimal from the nutritional perspective. Furthermore, rapeseed oil is characterized by the lowest content of saturated fatty acids among all edible oils (Dubois et al., 2007). Preliminary investigations demonstrated the good nutritional quality of cold-pressed rapeseed oil, hence it may become a fine alternative in Poland to expensive imported olive oil.

The consumer demand for cold-pressed oils is predominantly determined by sensory properties. Virgin rapeseed oil is appreciated due to its unique fresh and mild taste, which resembles asparagus, cabbage or fresh green veges. These flavour qualities are directly correlated with the value of the oil. Seed-like, nutty, woody and astringent attributes have been found useful and typical for sensory assessment for good-quality cold-pressed oils from high-quality seeds (Brühl and Matthäus, 2008; Matthäus and Brühl, 2003). This study investigated the effects of different contents of impurities in rapeseeds originating from conventional (seeds of individual cultivars and industrial seeds) and certified ecological seeds on the sensory quality, physicochemical properties and oxidative stability of rapeseed oil produced by cold-pressing.

\section{MATERIAL AND METHODS}

\section{Rapeseed}

The seeds of double improved rape from conventional and ecological farming, seeds from individual cultivars and industrial seeds were collected. The seeds from individual cultivars were provided by the Plant Breeding Strzelce, IHAR Group, Poland from the following cultivars: Starter, Monolit, Bojan, and Brendy (No. 1-4). Industrial seeds from conventional crops were collected from grain elevators from various regions i.e. Lubelskie, Mazowieckie, Śląskie, Opolskie and Wielkopolskie provinces, from one campaign from 2014 (No. 5-12). Certified ecological seeds of rape originated from individual farmers (No. 13-15).

Considering the highly significant effect of seed quality on their technological value, before the technological part of the study, it was deemed necessary to analyse the raw material in terms of basic quality attributes, i.e. the useful and useless impurities and impurities in total (PN-91/R-66160:1991), as well as the moisture (ISO 665:2000) and oil content of the seeds by automated Soxhlet extraction (Soxtec ${ }^{\mathrm{TM}} 2050$ Auto Fat Extraction System).

\section{Oil extraction by cold-pressing}

Portions of particular batches of seeds were coldpressed in a screw-press with a nozzle diameter of $\varnothing 8 \mathrm{~mm}$ (Farmer 10, Farmet, Czech Republic). The temperature inside the press was $60 \pm 10^{\circ} \mathrm{C}$ and the temperature of the outflowing oil was $39 \pm 1{ }^{\circ} \mathrm{C}$. After pressing, oil was collected, subjected to natural decantation under refrigerating conditions and analysed within one week. For each sample 2 measurements were taken.

\section{Sensory evaluation of oils}

Sensory evaluation was performed in duplicate by a selected and trained panel consisting of 10 persons 
in accordance with ISO 4121:2010 standard. The oil samples $(15 \mathrm{ml})$ were served in vessels at $\left.20 \pm 2^{\circ} \mathrm{C}\right)$. The sensory profile of the oils was determined in accordance with the reference-sensory assessment of virgin rapeseed oils (Brühl and Matthäus, 2008). Seven flavour attributes - seed-like, nutty, woody, strawy, astringent, rancid, fusty/musty - were chosen. A quantitative sensory description was conducted using a graded 10-point scale to measure the intensity of attributes, leading from zero ("not detec") to ten ("intense"). The data obtained, after conversion from a linear scale into numerical data, were presented as a graphic projection of PCA.

\section{Determination of the physicochemical properties of the oil}

The acid value (AV), peroxide value (PV), anisidine value $(p-\mathrm{AnV})$, and specific UV extinctions ( $K$ values) were determined in accordance with ISO standard methods (660:2009; 3960:2005; 68852008; $3656: 2002$, respectively). The oxidative stability of the oil samples was determined at $120^{\circ} \mathrm{C}$, in accordance with ISO 6886:1997 with Rancimat apparatus (Metrohm model 743; Metrohm KEBO Lab AB, Herisau, Switzerland). The total chlorophyll pigments, expressed as pheophytin $a$, were determined according to the AOCS method (1997) by measuring the absorbance of the oil against air at 630, 670, and $710 \mathrm{~nm}$.

\section{Statistical analysis}

Variables were compared by one-way ANOVA, when the variables fulfilled parametric conditions, or by the Kruskal-Wallis test, when these were non-parametric, using Statgraphics 4.1 software (Statpoint Technologies, Inc., Warrenton, VA, USA). Significant differences between means were determined through Duncan's Multiple Range Tests. P values less than 0.05 were considered as statistically significant. Pearsons's correlation coefficients between the level of impurities in seeds and sensory attributes, $\mathrm{AV}, \mathrm{PV}, \mathrm{AnV}$, IP, and the content of pheophytin $a$ were calculated and the values are presented in Table 4. Additionally, data were subjected to principal component analysis (PCA) and hierarchical cluster analysis (HCA) applying XLSTAT software (Addinsoft, Paris, France; version 2014.6.04).

\section{RESULTS AND DISCUSSION}

\section{Seeds quality}

The content of total impurities in seeds was within a very wide range, i.e. from 0.9 to $13.1 \%$ (Table 1). However, in the case of half of the batches of industrial rapeseeds analysed (No. 5-8, 10-11), it exceeded the 5\% limit specified in PN-R-66151:1990, while the highest content of useless impurities (6.9\%) and impurities in total (13.1\%) was found in certified ecological rapeseeds (No. 14). Impurity content below $2 \%$ was found only in 6 batches of seeds (No. 1-4, 12, 15). Excessive quantities were reported for both useful and useless impurities, including mainly damaged seeds and small parts of stems, but also seeds of other nonoil crops - cereals. These useful impurities included mainly rapeseeds partially or completely devoid of a seed coat and undeveloped seeds. An excessively high content of impurities has a negative impact on the yield of technological processes, as well as on the quality of oil and its oxidative stability, hence their removal from the raw material before pressing is of key significance (Matthäus, 2012; Matthäus and Brühl, 2008).

The rapeseeds were characterized by various water content levels that ranged from 4.7 to $7.1 \%$ (Table 1), but were still at the appropriate, recommended level. Water is a significant factor that controls seeds respiration and affects the growth of microflora and the activity of native enzymes. Water content in rapeseeds reaching $5-7 \%$ is optimal and indispensable to ensure safe storage up to 2 years without any greater technological and qualitative losses (Matthäus, 2012).

The oil content of the seeds was typical and ranged from 36.4 to $46.6 \%$ (average $42.1 \%$ ) (Table 1). The average content of oil in industrial seeds of Polish winter rapeseed ranges from 34 to $42 \%$, whereas in the seeds of individual cultivars it reaches even $50 \%$. Five of the seed batches analysed had a high fat content, i.e. above $44-46.6 \%$ (No. 1-3, 12, 15). In turn, a few batches were characterized by a very low content of fat amounting to 36.4 or $39.1 \%$ (No. 7, 10, 14).

\section{Sensory assessment of oils}

In order to differentiate the oil samples based on their sensory profile the PCA was applied to the mean ratings of each rapeseed oil sample across the seven 
Wroniak, M., Rękas, A., Ratusz, K. (2016). Influence of impurities in raw material on sensory and physicochemical properties of cold-pressed rapeseed oil produced from conventionally and ecologically grown seeds. Acta Sci. Pol. Technol. Aliment., 15(3), 289-297. DOI: 10.17306/J.AFS.2016.3.28

Table 1. Characteristics of seed samples used in research, $\%$

\begin{tabular}{|c|c|c|c|c|c|}
\hline Seeds & Total impurities & Useful impurities & Useless impurities & Moisture content & Oil content \\
\hline \multicolumn{6}{|c|}{ Seeds of individual cultivars } \\
\hline 1 & $1.3 \pm 0.1^{\mathrm{a}}$ & $1.2 \pm 0.1^{\mathrm{b}}$ & $0.1 \pm 0.0^{\mathrm{a}}$ & $6.7 \pm 0.2^{\mathrm{c}}$ & $44.7 \pm 0.2^{\mathrm{d}}$ \\
\hline 2 & $1.0 \pm 0.2^{\mathrm{a}}$ & $0.9 \pm 0.1^{\mathrm{ab}}$ & $0.1 \pm 0.0^{\mathrm{a}}$ & $6.4 \pm 0.1^{\mathrm{c}}$ & $44.1 \pm 0.1^{\mathrm{d}}$ \\
\hline 3 & $1.2 \pm 0.1^{\mathrm{a}}$ & $1.0 \pm 0.1^{\mathrm{b}}$ & $0.2 \pm 0.0^{\mathrm{a}}$ & $6.5 \pm 0.1^{\mathrm{c}}$ & $45.0 \pm 0.2^{\mathrm{d}}$ \\
\hline 4 & $1.2 \pm 0.1^{\mathrm{a}}$ & $1.0 \pm 0.1^{\mathrm{b}}$ & $0.2 \pm 0.0^{\mathrm{a}}$ & $6.3 \pm 0.0^{\mathrm{c}}$ & $43.7 \pm 0.3^{\mathrm{c}}$ \\
\hline \multicolumn{6}{|c|}{ Industrial seeds from conventional crops } \\
\hline 5 & $5.4 \pm 0.4^{\mathrm{e}}$ & $3.7 \pm 0.4^{\mathrm{d}}$ & $1.7 \pm 0.3^{\mathrm{c}}$ & $4.8 \pm 0.2^{\mathrm{a}}$ & $40.3 \pm 1.0^{\mathrm{c}}$ \\
\hline 6 & $7.3 \pm 0.5^{\mathrm{g}}$ & $5.3 \pm 0.5^{\mathrm{e}}$ & $2.0 \pm 0.6^{\mathrm{d}}$ & $4.9 \pm 0.1^{\mathrm{a}}$ & $40.9 \pm 1.3^{\mathrm{c}}$ \\
\hline 7 & $9.2 \pm 1.1^{\mathrm{h}}$ & $7.6 \pm 0.8^{\mathrm{g}}$ & $1.6 \pm 0.4^{\mathrm{c}}$ & $4.7 \pm 0.2^{\mathrm{a}}$ & $39.1 \pm 1.2^{\mathrm{b}}$ \\
\hline 8 & $4.9 \pm 0.3^{\mathrm{d}}$ & $3.8 \pm 0.3^{\mathrm{d}}$ & $1.1 \pm 0.1^{\mathrm{b}}$ & $5.1 \pm 0.1^{\mathrm{b}}$ & $39.9 \pm 1.8^{\mathrm{b}}$ \\
\hline 9 & $4.6 \pm 1.0^{\mathrm{d}}$ & $2.4 \pm 0.4^{\mathrm{c}}$ & $2.2 \pm 0.8^{\mathrm{d}}$ & $4.8 \pm 0.1^{\mathrm{a}}$ & $43.4 \pm 0.0^{c}$ \\
\hline 10 & $7.0 \pm 0.6^{\mathrm{f}}$ & $5.4 \pm 0.4^{\mathrm{e}}$ & $1.6 \pm 0.3^{\mathrm{c}}$ & $5.6 \pm 0.2^{b}$ & $39.3 \pm 0.2^{\mathrm{b}}$ \\
\hline 11 & $8.2 \pm 0.5^{\mathrm{g}}$ & $5.8 \pm 0.4^{\mathrm{e}}$ & $2.4 \pm 0.2^{\mathrm{d}}$ & $7.1 \pm 0.4$ & $40.9 \pm 0.3^{c}$ \\
\hline 12 & $1.8 \pm 0.3^{\mathrm{c}}$ & $1.5 \pm 0.3^{\mathrm{b}}$ & $0.3 \pm 0.1^{\mathrm{a}}$ & $5.6 \pm 0.6^{\mathrm{b}}$ & $44.9 \pm 0.6^{c}$ \\
\hline \multicolumn{6}{|c|}{ Certified ecological seeds } \\
\hline 13 & $6.1 \pm 1.3^{\mathrm{f}}$ & $2.6 \pm 0.2^{\mathrm{c}}$ & $3.5 \pm 1.3^{\mathrm{e}}$ & $4.9 \pm 0.1^{\mathrm{a}}$ & $42.6 \pm 0.7^{c}$ \\
\hline 14 & $13.1 \pm 1.2^{\mathrm{i}}$ & $6.2 \pm 0.8^{\mathrm{f}}$ & $6.9 \pm 0.8^{f}$ & $5.5 \pm 0.6^{\mathrm{b}}$ & $36.4 \pm 0.7^{\mathrm{a}}$ \\
\hline 15 & $0.9 \pm 0.1^{\mathrm{b}}$ & $0.6 \pm 0.2^{\mathrm{a}}$ & $0.3 \pm 0.1^{\mathrm{a}}$ & $6.1 \pm 0.3^{\mathrm{c}}$ & $46.6 \pm 0.8^{\mathrm{d}}$ \\
\hline
\end{tabular}

Mean values denoted by the same letter in the columns do not constitute statistically significant differences at $p<0.05(n=2 \times 3)$.

chosen attributes. The scores for the first two principal components of the 15 rapeseed varieties are presented in Figure 1. The first two principal components accounted for $83.03 \%$ ( $\mathrm{PC} 1=70.87 \%$ and $\mathrm{PC} 2=$ $12.16 \%$, respectively) of the total variation. The results presented in Table 2 demonstrate a strong correlation in the sensory attributes assigned to cold-pressed rapeseed oils, because the variability found in the samples is explained only by one component (PC1). PC1 was highly influenced by seed-like $(-0.953)$, nutty $(-0.862)$, strawy $(0.892)$, woody $(0.799)$, bitter (0.771), and fusty/musty (0.758) sensory attributes. Seed-like, nutty and astringent and woody flavour attributes are typical descriptors used for cold-pressed rapeseed oils flavour and aroma characterisation. On the other hand, strawy, rancid, fusty, musty attributes are identified as major rapeseed oil off-flavours (Brühl and Matthäus, 2008). The attribute 'seed-like' is typical of "cruciferous, brassica plants", and its taste resembles asparagus, cabbage or fresh green vegetables.

Principal component analysis - PCA applied to all samples shows a clear discrimination of oils, depending on the seed growing technique (Fig. 1). In fact, the flavour differences between oils were found along PC1 - oils produced from individual rapeseed cultivars are located on the upper left zone of the plane (samples No. 1-4), oils produced from industrial seed mixes are located mostly in the upper right-hand zone of the plane (samples No. 5-8), while oil samples obtained from ecological seeds are placed in the lower righthand portion of the bi-plot (samples No. 13-15). The PCA graph revealed that oils produced from individual 


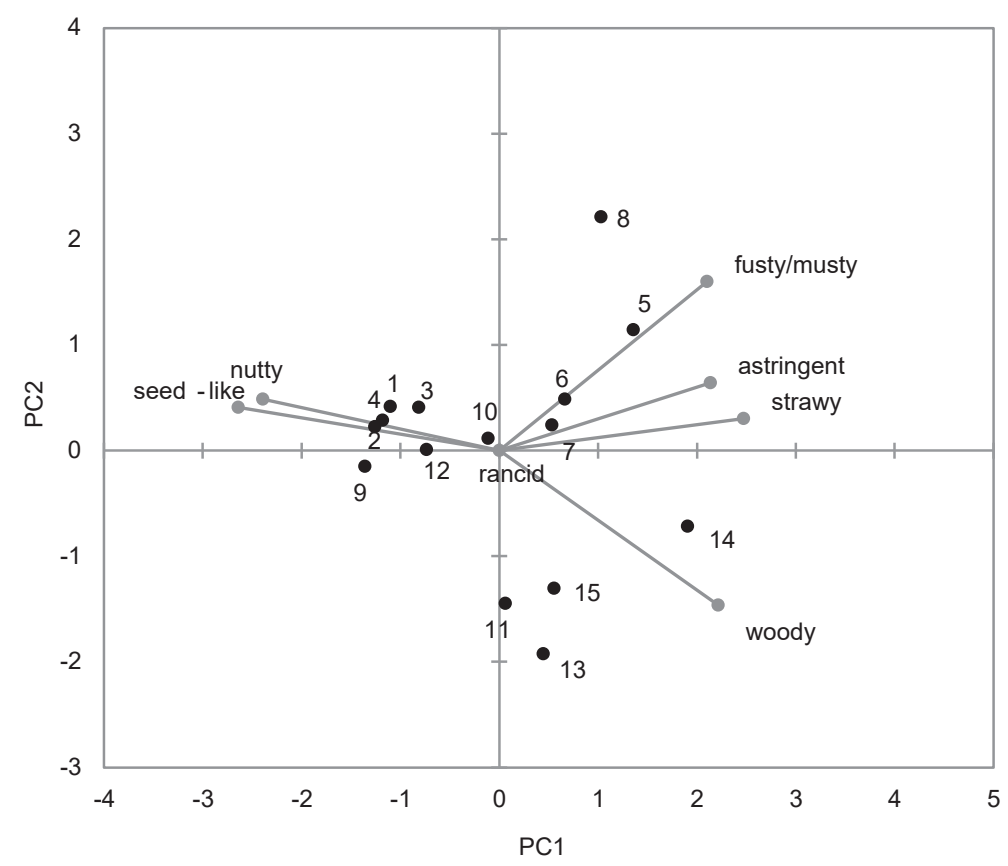

Fig. 1. PCA bi-plot based on sensory attributes profiling analysis of coldpressed rapeseed oils. Sample codes: cold-pressed rapeseed oils produced from - individual seeds cultivars (1-4), industrial seeds from conventional crops (5-12), certified ecological seeds (13-15)

Table 2. Principal component analysis (PCA) factor loadings for the sensory attributes of cold-pressed rapeseed oils produced from conventionally and ecologically grown seeds

\begin{tabular}{lcc}
\hline \multicolumn{1}{c}{ Sensory attribute } & PC1 & PC2 \\
\hline Seed-like & $\mathbf{- 0 . 9 5 3}$ & 0.147 \\
Nutty & $\mathbf{- 0 . 8 6 2}$ & 0.176 \\
Woody & $\mathbf{0 . 7 9 9}$ & -0.528 \\
Strawy & $\mathbf{0 . 8 9 2}$ & 0.109 \\
Bitter & $\mathbf{0 . 7 7 1}$ & 0.232 \\
Rancid & 0.000 & 0.000 \\
Fusty/musty & $\mathbf{0 . 7 5 8}$ & 0.577 \\
\hline
\end{tabular}

Values in bold are loadings with an absolute value greater than 0.70 .

rapeseed cultivars (sample No. 1-4) were characterized by strong seed-like and nutty sensory attributes. Strawy and fusty/musty off-flavours were perceivable in few oils from industrial seeds (samples No. 5-8), while a woody off-flavour was noticeable in oils acquired from ecological seeds (samples No. 13-15). The appearance of fusty, musty or rancid off-flavours may result from storage under inappropriate humidity (Brühl and Matthäus, 2008; Matthäus, 2008), while the presence of impurities in raw material (up to $10 \%$ ) exert an adverse effect on the sensory characteristics of the oil (Dimić et al., 2012). A positive correlation was found between the level of impurities in seeds and the appearance of woody $(r=0.847)$, astringent $(r=0.464)$ and fusty/musty ( $r=0.591$ ) off-flavours, as well as strawy $(r=0.630)$ sensory attribute. On the other hand, a negative correlation was reported between the impurity content in seeds and seed-like and nutty sensory attributes $(r=-0.870 ; r=-0.781$, respectively) (Table 4).

\section{Physicochemical properties of cold-pressed oils}

The quality of the seeds, including humidity, ripeness and seed damages and contamination mainly influences the advancement of disadvantageous hydrolytic and 
Wroniak, M., Rękas, A., Ratusz, K. (2016). Influence of impurities in raw material on sensory and physicochemical properties of cold-pressed rapeseed oil produced from conventionally and ecologically grown seeds. Acta Sci. Pol. Technol. Aliment., 15(3), 289-297. DOI: 10.17306/J.AFS.2016.3.28

oxidative changes ensuing in fats, lowering the oxidative stability and quality of the oil (Matthäus, 2008). The degree of hydrolysis, assessed in terms of changes in $\mathrm{AV}$, which was recorded for rapeseed oils produced from conventionally grown seeds (No. 1-12) ranged from 0.5 to $1.0 \mathrm{mg} \mathrm{KOH} / \mathrm{g}$, and thus remained below the threshold limit of $4 \mathrm{mg} \mathrm{KOH} / \mathrm{g}$ (Table 3) (Codex Stan, 2013). Surprisingly, oil produced from ecological seeds (No. 14) surpassed that limit (AV $=4.6 \mathrm{mg}$ / $\mathrm{KOH} / \mathrm{g}$ ) most likely due to exceptionally high impurity content (13\%). All oils fulfilled requirements pertaining to the peroxide value $\left(<15 \mathrm{meq} \mathrm{O}_{2} / \mathrm{kg}\right)$ specified in the Codex Alimentarius for cold-pressed oils. As expected, oils with the highest degree of hydrolysis and lipid oxidation were obtained from industrial seeds. The best quality in this regard was demonstrated by oils produced from seeds of individual cultivars, which can be attributed to the lowest content of impurities among all types of seeds tested. A high positive correlation was demonstrated between the impurity content of seeds and AV $(r=0.781)$ and PV $(r=0.656)$ (Table 4).

The content of secondary oxidation products, assessed in terms of AnV alterations, in the oils analysed did not exceed the value of 1.0 (except No. 14), and did not differ statistically significantly between one another. The highest $\mathrm{AnV}$ was determined for oil pressed from seeds with the highest level of impurities, which was consistent with findings presented by Rotkiewicz and Konopka (1998). This observation

Table 3. Physicochemical properties of cold-pressed rapeseed oils

\begin{tabular}{|c|c|c|c|c|c|c|c|}
\hline Oils & $\begin{array}{c}\mathrm{AV} \\
\mathrm{mg} \mathrm{KOH} / \mathrm{g}\end{array}$ & $\begin{array}{c}\mathrm{PV} \\
\mathrm{mEq} \mathrm{O}_{2} / \mathrm{kg}\end{array}$ & $\mathrm{AnV}$ & $K_{232}$ & $K_{268}$ & $\begin{array}{l}\text { IP } \\
\mathrm{h}\end{array}$ & $\begin{array}{c}\text { Pheophytin } a \\
\mathrm{mg} / \mathrm{kg}\end{array}$ \\
\hline \multicolumn{8}{|c|}{ Seeds of individual cultivars } \\
\hline 1 & $0.6 \pm 0.03^{\mathrm{a}}$ & $0.4 \pm 0.04^{\mathrm{a}}$ & $0.8 \pm 0.15^{\mathrm{a}}$ & $1.42 \pm 0.019^{\mathrm{b}}$ & $0.07 \pm 0.001^{\mathrm{a}}$ & $3.9 \pm 0.03^{\mathrm{a}}$ & $2.4 \pm 0.07^{\mathrm{b}}$ \\
\hline 2 & $1.1 \pm 0.06^{\mathrm{b}}$ & $0.5 \pm 0.07^{\mathrm{a}}$ & $0.4 \pm 0.08^{\mathrm{a}}$ & $1.48 \pm 0.026^{\mathrm{b}}$ & $0.11 \pm 0.003^{\mathrm{b}}$ & $3.8 \pm 0.04^{\mathrm{a}}$ & $2.1 \pm 0.28^{\mathrm{b}}$ \\
\hline 3 & $0.5 \pm 0.05^{\mathrm{a}}$ & $0.5 \pm 0.08^{\mathrm{a}}$ & $0.3 \pm 0.07^{\mathrm{a}}$ & $1.47 \pm 0.035^{\mathrm{b}}$ & $0.10 \pm 0.002^{\mathrm{b}}$ & $3.8 \pm 0.09^{\mathrm{a}}$ & $1.8 \pm 0.24^{\mathrm{a}}$ \\
\hline 4 & $1.5 \pm 0.03^{\mathrm{b}}$ & $0.5 \pm 0.01^{\mathrm{a}}$ & $0.4 \pm 0.09^{\mathrm{a}}$ & $1.50 \pm 0.026^{\mathrm{c}}$ & $0.11 \pm 0.002^{\mathrm{b}}$ & $3.6 \pm 0.08^{\mathrm{a}}$ & $5.7 \pm 0.53^{\mathrm{e}}$ \\
\hline \multicolumn{8}{|c|}{ Industrial seeds from conventional crops } \\
\hline 5 & $2.7 \pm 0.12^{\mathrm{c}}$ & $3.2 \pm 0.09^{d}$ & $0.6 \pm 0.08^{\mathrm{a}}$ & $1.82 \pm 0.045^{\mathrm{f}}$ & $0.26 \pm 0.001^{\mathrm{c}}$ & $3.8 \pm 0.13^{\mathrm{a}}$ & $6.5 \pm 0.28^{f}$ \\
\hline 6 & $1.6 \pm 0.04^{\mathrm{b}}$ & $2.2 \pm 0.20^{\mathrm{c}}$ & $0.6 \pm 0.10^{\mathrm{a}}$ & $1.51 \pm 0.024^{\mathrm{c}}$ & $0.12 \pm 0.024^{\mathrm{b}}$ & $4.4 \pm 0.10^{\mathrm{b}}$ & $4.0 \pm 0.18^{\mathrm{d}}$ \\
\hline 7 & $1.7 \pm 0.07^{\mathrm{b}}$ & $2.1 \pm 0.06^{\mathrm{c}}$ & $0.4 \pm 0.17^{\mathrm{a}}$ & $1.58 \pm 0.054^{\mathrm{c}}$ & $0.12 \pm 0.007^{\mathrm{b}}$ & $3.8 \pm 0.20^{\mathrm{a}}$ & $10.4 \pm 0.32^{\mathrm{i}}$ \\
\hline 8 & $2.3 \pm 0.08^{c}$ & $2.4 \pm 0.09^{c}$ & $0.6 \pm 0.08^{\mathrm{a}}$ & $1.61 \pm 0.028^{\mathrm{d}}$ & $0.13 \pm 0.002^{\mathrm{b}}$ & $4.1 \pm 0.14^{\mathrm{b}}$ & $5.6 \pm 0.22^{\mathrm{e}}$ \\
\hline 9 & $0.8 \pm 0.09^{\mathrm{a}}$ & $4.4 \pm 0.03^{\mathrm{e}}$ & $0.6 \pm 0.09^{\mathrm{a}}$ & $1.50 \pm 0.043^{\mathrm{c}}$ & $0.07 \pm 0.005^{\mathrm{a}}$ & $3.9 \pm 0.04^{\mathrm{a}}$ & $2.3 \pm 0.07^{\mathrm{b}}$ \\
\hline 10 & $1.4 \pm 0.05^{\mathrm{b}}$ & $2.3 \pm 0.09^{c}$ & $0.5 \pm 0.31^{\mathrm{a}}$ & $1.54 \pm 0.010^{\mathrm{c}}$ & $0.12 \pm 0.003^{\mathrm{b}}$ & $4.7 \pm 0.13^{\mathrm{b}}$ & $6.3 \pm 0.25^{\mathrm{f}}$ \\
\hline 11 & $2.0 \pm 0.06^{\mathrm{c}}$ & $2.8 \pm 0.15^{\mathrm{c}}$ & $0.7 \pm 0.16^{\mathrm{a}}$ & $1.79 \pm 0.155^{\mathrm{e}}$ & $0.21 \pm 0.003^{\mathrm{c}}$ & $3.9 \pm 0.13^{\mathrm{a}}$ & $9.2 \pm 0.21^{\mathrm{h}}$ \\
\hline 12 & $1.0 \pm 0.13^{\mathrm{b}}$ & $2.0 \pm 0.07^{\mathrm{c}}$ & $0.5 \pm 0.17^{\mathrm{a}}$ & $1.58 \pm 0.078^{c}$ & $0.15 \pm 0.011^{\mathrm{b}}$ & $4.2 \pm 0.17^{\mathrm{b}}$ & $7.6 \pm 0.27^{\mathrm{g}}$ \\
\hline \multicolumn{8}{|c|}{ Certified ecological seeds } \\
\hline 13 & $1.3 \pm 0.04^{\mathrm{b}}$ & $3.5 \pm 0.09^{\mathrm{d}}$ & $0.6 \pm 0.12^{\mathrm{a}}$ & $2.04 \pm 0.060^{\mathrm{g}}$ & $0.12 \pm 0.006^{\mathrm{b}}$ & $3.6 \pm 0.10^{\mathrm{a}}$ & $3.0 \pm 0.52^{\mathrm{c}}$ \\
\hline 14 & $4.6 \pm 0.14^{\mathrm{d}}$ & $3.2 \pm 0.10^{\mathrm{d}}$ & $1.6 \pm 0.28^{\mathrm{b}}$ & $1.87 \pm 0.053^{\mathrm{f}}$ & $0.19 \pm 0.006^{\mathrm{b}}$ & $3.8 \pm 0.08^{\mathrm{a}}$ & $9.2 \pm 0.16^{\mathrm{h}}$ \\
\hline 15 & $0.5 \pm 0.05^{\mathrm{a}}$ & $1.0 \pm 0.09^{\mathrm{b}}$ & $0.5 \pm 0.18^{\mathrm{a}}$ & $1.31 \pm 0.043^{\mathrm{a}}$ & $0.09 \pm 0.009^{\mathrm{a}}$ & $5.4 \pm 0.29^{\mathrm{c}}$ & $1.6 \pm 0.34^{\mathrm{a}}$ \\
\hline
\end{tabular}

Mean values denoted by the same letter in the columns do not constitute statistically significant differences at $p<0.05(n=2 \times 3)$. 
Wroniak, M., Rękas, A., Ratusz, K. (2016). Influence of impurities in raw material on sensory and physicochemical properties of cold-pressed rapeseed oil produced from conventionally and ecologically grown seeds. Acta Sci. Pol. Technol. Aliment., 15(3), 289-297. DOI: 10.17306/J.AFS.2016.3.28

Table 4. Pearsons's correlation coefficients between the content of impurities and sensory attributes, AV, PV, AnV, oxidative stability (IP), and pheophytin $a$ concentration

\begin{tabular}{lc}
\hline & Total impurities \\
\hline Seed-like & -0.870 \\
Nutty & -0.781 \\
Astringent & 0.464 \\
Strawy & 0.630 \\
Woody & 0.847 \\
Fusty/musty & 0.591 \\
AV & 0.781 \\
PV & 0.656 \\
AnV & 0.645 \\
$K_{232}$ & 0.625 \\
$K_{268}$ & 0.489 \\
IP & -0.155 \\
Pheophytin $a$ & 0.692 \\
\hline
\end{tabular}

was confirmed by the results of Pearson's correlation, where a significant positive correlation was demonstrated between the AnV and the level of impurities in raw material $(r=0.645)$. The relative oxidation degree is quantified using changes in spectrophotometric indices. The content of dienes $\left(K_{232}\right)$ is a consequence of primary oxidation, whereas the presence of trienes $\left(K_{268}\right)$ indicates the formation of oxidation by-products such as unsaturated $\alpha$ - and $\beta$-diketones and $\beta$-ketones. Although determining $\mathrm{K}$ values is a method widely used in oil analysis, only limits for olive oils have been determined (EC Regulation 61/2011). The $K_{232}$ values ranged from 0.91 to 2.04 , whereas the $K_{268}$ values from 0.07 to 0.26 , hence the oils analysed were characterized by a low degree of primary and secondary oxidation, which was correlated with respectively low PV and $\mathrm{AnV}$ of the oils. Similar results were achieved for virgin rapeseed oil by Tynek et al. (2012) $\left(K_{232}\right.$ from 0.896 to 1.990 , and $K_{268}$ from 0.056 to 0.302 , respectively).

The results of an oil oxidative stability evaluation based on the Rancimat test are presented in Table 3.
The induction periods of the cold-pressed oils that were tested ranged from 3.6 to $5.4 \mathrm{~h}$, which is in agreement with the results obtained by Pekkarinen et al. (1998), Matthäus and Brühl (2003), Wroniak et al. $(2006 ; 2008)$. According to literature data, the oxidative stability of cold-pressed rapeseed oils is influenced by many factors, especially fatty acid composition, antioxidants, mainly tocopherols and minor compounds. As mentioned previously, the quality of raw material itself is of great importance, too. However, in the case of oxidative stability, no significant correlation was found between the level of impurities in seeds and the IP of the resulting oils.

The chlorophyll pigment content in cold-pressed oil is of great significance owing to the colour deterioration of this type of oil, as well as to the potential participation in photosensibilized oxidation and thereby its contribution to the reduced oxidative stability of oil. The main chlorophyll pigments of rapeseeds include chlorophyll $a$, whereas rapeseed oil contains mainly pheophytin $a$ (Choe and Min, 2006). The pheophytin $a$ content in the oils which were analysed ranged from 1.6 to $10.4 \mathrm{mg} / \mathrm{kg}$ in various batches depending on the quality of seeds (Table 3 ) and it was positively correlated with the impurity content in seeds $(r=0.692)$. The pheophytin $a$ content determined in the coldpressed oils analysed was higher than the values presented by Tynek et al. (2012) (less than $1 \mathrm{mg} / \mathrm{kg}$ ), but lower than the values reported by Matthäus and Brühl (2003) (20-60 mg/kg). The low content of chlorophyll pigments in cold-pressed oil indicates the full ripeness of processed rapeseeds, in which a reduction in chlorophyll content in the last few days before reaching ripeness may decrease even 100 times (Matthäus, 2012).

A dendrogram formed using complete linkage clustering (the farthest neighbour clustering) showed a correlation between seed origin and the quality of the resulting oils. Figure 2 shows the dendrogram, where 2 distinct clusters can be identified. Cluster 1 contains oils produced from certified ecological seeds (No. 13-15), as well as oils derived from industrial seeds (No. 8, 10-12). Cluster 2 contains two distinct subclusters: the first connects cold-pressed oils derived from individual rapeseed cultivars (No. 1-4), while the second connects oils from industrial seeds (No. 5-7, 9). Hierarchical cluster analysis (HCA) was capable 


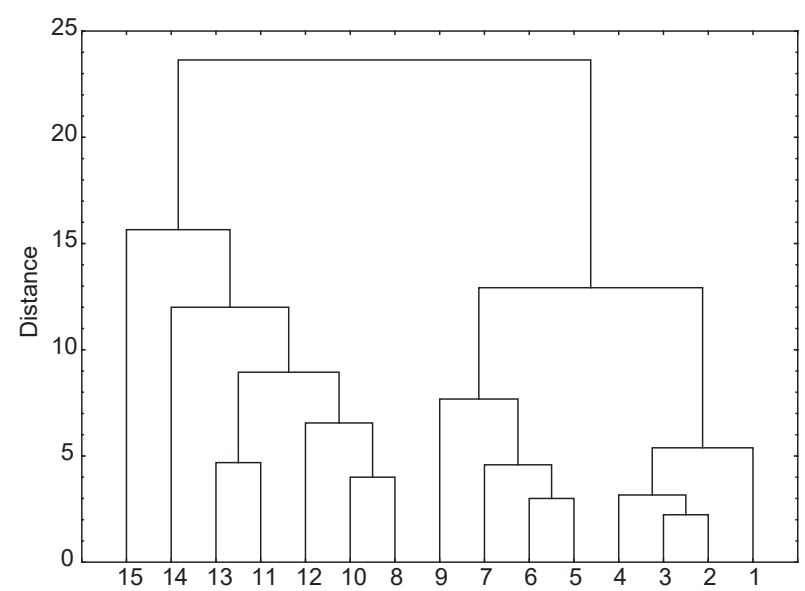

Fig. 2. Hierarchical cluster analysis (HCA) dendrogram of cold-pressed rapeseed oils produced from ecologically and conventionally grown seeds, grouped using the complete linkage clustering with Euclidean distances. Sample codes: cold-pressed rapeseed oils produced from - individual seeds cultivars (1-4), industrial seeds from conventional crops (5-12), certified ecological seeds (13-15)

of differentiating between rapeseed oils acquired from seeds of different origin. Seeds homogenous in terms of cultivar were characterized by a minimal impurity content and the resulting oils were of the highest quality, differing significantly in this regard from the oils pressed from ecological and industrial seeds. The latter types of seeds differ slightly between each other in terms of their impurity content and oils derived from these seeds shared similar physicochemical properties.

\section{CONCLUSIONS}

It has been concluded that both the presence of impurities and rapeseed's origin have an impact on the sensory characteristics and physicochemical quality of coldpressed oils. It has been demonstrated that rapeseeds with an impurity content of $<1 \%$ are most suitable for cold-pressing. Their use ensures the production of oil with low degrees of hydrolysis and oxidation corresponding to those of refined oil. The presence of impurities exceeding 5\% in the starting material for pressing have a negative effect on the sensory quality of cold-pressed rapeseed oil; the presence of impurities at such a level was associated with the appearance of woody, strawy and fusty/musty off-flavours. However, no correlation between the impurity content and oxidative stability of the oils tested was found. The highest-quality cold-pressed rapeseed oil was obtained by pressing the seeds originating from individual cultivars, characterized by the lowest impurity content. It seems advisable, therefore, to remove impurities from the raw material prior to pressing, in order to produce high-quality cold-pressed rapeseed oil.

\section{REFERENCES}

AOCS (1997). Recommended PracticeCc 13i-96, Sampling and analysis of commercial fats and oils: Determination of chlorophyll pigments in crude vegetable oils.

Brühl, L., Matthäus, B. (2008). Sensory assessment of virgin rapeseed oils. Eur. J. Lipid Sci. Technol., 110, 608-610.

Choe, E., Min, D. (2006). Mechanisms and factors for edible oil oxidation. Comp. Rev. Food Sci. F., 5, 169-186.

Codex Alimentarius FAO/WHO: Fats, oils and related products. Codex Standard for Edible Fats and Oils Not Covered by Individual Standards. (CODEX STAN 210 1999).

Dimić, K., Premović, T., Takači, A. (2012). Effects of the contents of impurities and seed hulls on the quality of cold-pressed sunflower oil. Czech J. Food Sci., 30, 343-350.

Dubois, V., Breton, S., Linder, M., Fanni, J., Parmentier, M. (2007). Fatty acid profiles of 80 vegetable oils with regard to their nutritional potential. Eur. J. Lipid Sci. Technol., 109, 710-732.

European Commission (2011). Commission Regulation (EU) No 61/2011 of 24 January 2011 amending Regulation (EEC) No 2568/91 on the characteristics of olive oil and olive-residue oil and on the relevant methods of analysis.

Gupta, M. K. (2005). Frying oils. In F. Shahidi (Ed.), Bailey's industrial oil and fat products (Vol. 6, pp. 1-31). New Jersey: John Wiley and Sons Interscience.

ISO 3656:2011. Animal and vegetable fats and oils. Determination of ultraviolet absorbance expressed as specific UV extinction.

ISO 3960:1996. Animal and vegetable fats and oils. Determination of peroxide value.

ISO 4121:2010. Sensory analysis. Guidelines for the use of quantitative response scales.

ISO 660:2005. Animal and vegetable fats and oils. Determination of acid value and acidity.

ISO 665:2000. Methods for analysis of oilseeds. Determination of moisture and volatile matter content. 
Wroniak, M., Rękas, A., Ratusz, K. (2016). Influence of impurities in raw material on sensory and physicochemical properties of cold-pressed rapeseed oil produced from conventionally and ecologically grown seeds. Acta Sci. Pol. Technol. Aliment., 15(3), 289-297. DOI: 10.17306/J.AFS.2016.3.28

ISO 6885:2008. Animal and vegetable fats and oils. Determination of anisidine value.

ISO 6886:1997. Animal and vegetables fats and oils. Determination of oxidation stability. Accelerated oxidation test.

Koski, A., Psomiadou, E., Tsimidou, M., Hopia, A., Kefalas, P., Wähälä, K., Heinonen, M. (2002). Oxidative stability and minor constituents of virgin olive oil and cold-pressed rapeseed oil. Eur. Food Res. Technol., 214, 294-298.

Matthäus, B. (2008). Production of high-quality virgin rapeseed oil - why so difficult? In Advances in analysis and technology of rapeseed oil. Monograph (pp. 139-150). Toruń, Poland: Wydawnictwo Naukowe Uniwersytetu Mikołaja Kopernika.

Matthäus, B. (2012). Oil technology. In S. K. Gupta (Ed.), Technological innovations in major world oil crops. Vol. 2. Perspectives (pp. 23-92). New York: Springer Science + Business Media.

Matthäus, B., Brühl, L. (2003). Quality of cold-pressed edible rapeseed oil in Germany. Nahrung/Food, 47, 413-419.

Matthäus, B., Brühl, L. (2008). Why is it so difficult to produce high-quality virgin rapeseed oil for human consumption? Eur. J. Lipid Sci. Technol., 110, 611-617.

Matthäus, B., Spener, F. (2008). What we know and what we should know about virgin oils - a general introduction. Eur. J. Lipid Sci. Technol., 110, 597-601.

Pekkarinen, S., Hopia, A., Heinonen, M. (1998). Effect of processing on the oxidative stability of low erucic acid turnip rapeseed (Brassica rapa) oil. Fett/Lipid, 100, 69-74.

PN-91/R-66160:1991. Rośliny przemysłowe oleiste. Oznaczanie zanieczyszczeń i szkodników w ziarnie rzepaku i rzepiku [Industrial oil plants. Determination of impurities and pests in rape and turnip rape seeds] [in Polish].

PN-R-66151:1990. Rośliny przemysłowe oleiste. Ziarno rzepaku i rzepiku podwójnie ulepszonego [Industrial oil plants. Double low rape and turnip rape seeds] [in Polish].

Rotkiewicz, D., Konopka, I. (1998). Trwałość olejów rzepakowych tłoczonych na zimno z nasion o zróżnicowanej jakości [Stability of cold pressed oils from the rapeseed of different quality]. Rośl. Oleist. - Oilseed Crops, 19, 583-591 [in Polish; English abstract].

Rotkiewicz, D., Tańska, M., Konopka, I. (2002). Wymiary nasion rzepaku jako czynnik kształtujący ich wartość technologiczną oraz jakość oleju [Seed size of rapeseed as a factor determining their technological value and quality of oil]. Rośl. Oleist., 23, 103-112 [in Polish; English abstract].

Tynek, M., Pawłowicz, R., Gromadzka, J., Tylingo, R., Wardecki, W., Karlovits, G. (2012). Virgin rapeseed oils obtained from different rape varieties by cold pressed method - their characteristics, properties and differences. Eur. J. Lipid Sci. Technol., 114, 357-366.

Wroniak, M., Krygier, K., Kaczmarczyk, M. (2008). Comparison of the quality of cold pressed and virgin rapeseed oils with industrially obtained oils. Pol. J. Food Nutr. Sci., 58, 85-89.

Wroniak, M., Łukasik, D., Maszewska, M. (2006). Porównanie stabilności oksydatywnej wybranych olejów tłoczonych na zimno z olejami rafinowanymi [Comparison of the oxidative stability of some selected cold-pressed and fully refined oils]. Żywn. Nauka Techn. Jakość, 1(46), Supl, 214-221 [in Polish; English abstract]. 
